\title{
To identify hazards and risks (Health and safety) in the textile dyeing industry
}

\author{
NAZNEEN JABEEN AND ARUSHI JABEEN
}

Received: 16.03.2017; Revised: 22.04.2017; Accepted: 07.05.2017

See end of the paper for authors' affiliations NAZNEEN JABEEN

Department of Home Science, Chhatrapati Shivaji Mahavidhaliya, Bahadurgarh, HAPUR (U.P.) INDIA
DABSTRACT : The present study was planned in order to identify hazards and risks (Health and safety) workers who are working in dyeing industry. Longer the duration of work more may be the effects of the dye on human body Since dyeing industries work with corrosive chemicals, reactive dyes, hazardous solvents and other toxic and substance, the long term contact and exposure affected people's health. Therefore there was a need to study the effects of the dyeing chemicals on the health of the place. This would create awareness about their safety and precaution to be taken during the operations. Such hazards when identified proper action could be carried out to illuminate the short comings and defects.

KEY WORDS: Health hazards, Safety risk, Textile dyeing industry

- HOW TO CITE THIS PAPER : Jabeen, Nazneen and Jabeen, Arushi (2017). To identify hazards and risks (Health and safety) in the textile dyeing industry. Asian J. Home Sci., 12 (1) : 182-187, DOI: 10.15740/HAS/AJHS/12.1/182-187. 